\title{
Project-based learning used for teaching electrical installations and lighting installations in architecture
}

\author{
Alicia Martínez Antón, Nuria Castilla Cabanes, Rosa Pastor Villa, Vicente Blanca Giménez \\ Departamento de Construcciones Arquitectónicas - Universitat Politècnica de València (SPAIN) \\ almaran@,csa.upv.es; ncastilla@,csa.upv.es; ropasvil@,csa.upv.es; vblanca@,csa.upv.es
}

Received December 2010

Accepted April 2011

\section{Abstract:}

Purpose: This paper discusses the use of Project-Based Learning (PBL) in the subject "Acondicionamiento y Servicios 2", which is taught at the Escuela de Arquitectura at the UPV.

\section{Design/methodology/approach: Case study.}

Findings: The results show that the goals (motivation, improved learning outcomes, independent learning and connection with professional practice), which led to the introduction of this kind of learning, have been achieved.

Research limitations/implications: This work has been proved in two groups of a subject. Therefore, conclusions are specifically related to this context and generalization is not proved.

Practical implications: Increase motivation, improved learning outcomes, independent learning and connection with professional practice.

Originality/value: This work confirms previous studies about the useful of PBL in engineering matters.

Keywords: projects, cooperative work, formative assessment, motivation, electrical installations, lighting installations 


\section{Introduction}

Architecture students find dealing with building installations project difficult and often they design them in the final stage of their architectural project, leaving them as an add-on that is poorly integrated into the building. In large part this is probably due to architecture students' lack of interest in and motivation for installations. The only time in their degree programme that students design the installations of a building they have designed is during their Final Degree Project.

This paper discusses the use of Project-Based Learning (PBL) in the subject "Acondicionamiento y Servicios 2", which is taught by the Escuela de Arquitectura at the Universitat Politècnica de València (UPV). The subject matter comes from an engineering field, specifically industrial engineering, but is taught on the Architecture degree programme.

PBL is a teaching method whereby students plan and develop projects connected to the professional world (Blank, 1997). As a result, one of the main goals is that students should learn by doing, acquiring an appropriate method for addressing the problems they will face in their future professional practice (Fernández, 2003).

The PBL method is especially suitable for technical subjects in which students also have to use, integrate and implement what they have learned in a number of subjects. In the case discussed in this paper, PBL is a very useful way of getting students in the middle years of their degree used to integrating the material they have learned so far (structures, construction, building projects and installations) and thus conceiving of an architectural design as a whole.

The main aspects of PBL have been extracted so as to adapt them to the special features of the subject in which it has been used (Blank, 1997; Harwell, 1997; Fernández, 2003):

- Project-based activities connected to professional reality

- A project on a large enough scale to be developed throughout the academic year 
- Integration of various courses and subjects

- Establishing a project implementation "guide"

- Cooperative work

- Public display of project and submission of the final report

- Accounting for at least $30 \%$ of the mark for the subject

Furthermore, addressing cooperative work is critical for the development of the projects. There is thus a need to pay special attention to the design of the activity/project to take into account the five ingredients of cooperative learning (Johnson, Johnson \& Smith, 1991).

- Positive interdependence

- Individual accountability

- Face-to-face promotive interaction

- Appropriate use of collaborative skills

- Group processing

The method set out in this paper involves cooperative learning and formative assessment as basic and complementary components of PBL.

The paper is structured as follows. In Section 2 we present a brief review of the fundamentals of PBL and its application to higher education. Section 3 describes specifications of the subject where this study has been applied. In Section 4, the starting point and the reasons for the need to change the way the subject is taught are analyzed. Section 5 focuses on the implementation of PBL in the subject. Finally, Section 6 contains an assessment of the practical use of the method which includes a discussion of the results that confirm the success of the methodology.

\section{Related work}

As has been briefly introduced in previous section, Project Based Learning (PBL) is a teaching method whereby students plan and develop projects connected to the 
professional world (Blank, 1997). This methodology has shown to be especially adequate in the context of engineering studies since the development of technical projects is closely related to the engineer or architect work (Woods, 2000).

PBL organizes learning around the development of a real-life project that is presented to the students as a motivating challenge. The project is designed with the purpose of developing in the students a depth learning of the essential knowledge along with very important professional and social skills. These skills include, among others: organization, decision making, research, reflection, autonomous and cooperative work, problem solving, and communication skills.

PBL has been progressively applied in the English speaking world to higher education since 1970s. One of the first applications of PBL to higher education was carried out in the McMaster University (Ontario, Canada) for use with medical studies (Woods, 1994). Also, a very important application of PBL has been performed in the Aalborg University (Denmark) known as the Aalborg PBL Model (Kjersdam \& Enemark, 1994). This institution has developed and adopted a systematic framework for the PBL to education since all university programmes have been base on PBL. Another interesting examples of PBL application to European higher education are: Roskilde University (Denmark); Maastricht University, Delf University of Technology, Eindhoven University of Technology and University of Twente (Holland); Linköping University (Sweden); and Norwergian University of Science and Technology (Norway).

PBL can be applied in different scenarios, i.e.: single subjects, group of subjects, the whole program of studies, or even more all university programmes (as the mentioned Aalborg University). Even so, subjects with a significant number of ECTS (European Credit Transfer System) are more suitable scenario for PBL since students' skills can be developed more appropriately (Valero-García, 2010).

Recent and innovative experiences of applying PBL in these different contexts can be found in the Spanish universities. On the one hand, Universitat Autònoma de Barcelona has applied PBL to single subjects in the field of computer science achieving successful findings (Martí, Gil, Vivet \& Julià, 2009). Also, in the context of computer science at the University of Alicante, PBL has been applied to group of subjects showing that more complex projects can be designed when different subjects are involved (Reverte, Gallego, Molina \& Satorre, 2007). 
On the other hand, an example of PBL applied to the whole program of studies can be found in the Escola d'Enginyeria de Telecomunicació i Aeroespacial de Castelldefels (Universitat Politècnica de Catalunya) (Alcocer, Ruíz \& Valero-García, 2003). In this case, PBL has been applied to the second cycle in telecommunication engineering with a very positive evaluation of students and teachers.

In summary, PBL has shown to be a very useful learning model applied to higher education and, more specifically, in the context of engineering studies.

\section{Method}

This work analyzes the application of PBL in the context of a subject which specifications are shown in Table 1.

\begin{tabular}{|l|l|}
\hline \multicolumn{1}{|c|}{ Qualification } & \multicolumn{1}{|c|}{ Architect } \\
\hline University & Universitat Politècnica de València \\
\hline Centre & Escuela de Arquitectura \\
\hline Year & 4th (8th semester) \\
\hline Type & Core - compulsory, semester-long \\
\hline Credits & 8.5 (2002 Plan) \\
\hline Weeks & 13 \\
\hline Hours of theory classes per week & 3.5 (divided into two classes of 2 and 1.5 hours) \\
\hline Hours of practical classes per week & 2.5 \\
\hline Students & 561 \\
\hline General theory groups & 5 \\
\hline Average students per group & 112 \\
\hline Practical sub-groups in each theory group & 3 \\
\hline Maximum students per practical sub-group & 40 \\
\hline General content & $\begin{array}{l}\text { Block I. Environmental Conditioning } \\
\text { Block II. Electrical Installations } \\
\text { Block III. Lighting Installations }\end{array}$ \\
\hline
\end{tabular}

Table 1. "Specifications of the Acondicionamiento y Servicios 2 subject. Year 2009-10". Source: authors

\section{Analysis of the starting point}

Prior to the use of this method, students did a practical project per block in this subject throughout the year supervised by the lecturer. The 2.5 hours of practical 
classes per week were used for going over the work of those students who voluntarily attended. Coursework did not count towards the final mark and if passed would only mean the student did not have to do the practical exam.

Examination of the projects handed in by students at the end of the semester period and the results of final examinations led to the following conclusions:

- Most students experienced problems with calculating and using tables and formulas for sizing electrical installations

- The projects handed in contained serious conceptual mistakes

- Many students were not able to resolve lighting issues

- They lacked adequate design criteria for lighting and electrical installations

- Many projects had been copied from previous years

- According to information supplied by the students themselves and the results of official UPV surveys, the lack of motivation felt by the majority for the subject was obvious. This fact can be observed in Table 2 where the results of official UPV surveys regarding the question about motivation is summarized.

\begin{tabular}{|l|c|c|c|c|}
\cline { 2 - 5 } \multicolumn{1}{c|}{} & $\begin{array}{c}\text { Group D } \\
\text { Average } \\
\text { (out of 10) }\end{array}$ & $\begin{array}{c}\text { Standard } \\
\text { deviation }\end{array}$ & $\begin{array}{c}\text { Group E } \\
\text { Average } \\
\text { (out of 10) }\end{array}$ & $\begin{array}{c}\text { Standard } \\
\text { deviation }\end{array}$ \\
\hline Year 07-08 & 4.52 & 2.19 & 5.00 & 3.10 \\
\hline Year 08-09 & 5.73 & 3.37 & 6.22 & 2.48 \\
\hline
\end{tabular}

Table 2. "Results about the question "The methodology employed is motivating", formulated in the official UPV surveys of the previous academic years 07-08 and 08-09 of the groups D and E". Source: authors

Given this situation it seemed necessary to review the approach to coursework taken so far and bring in improvements. 


\section{Use of Project-Based Learning in the subject}

\subsection{Goals}

- Achieve better learning outcomes

- Nurture independent learning

- Increase the motivation of Architecture students for installations subjects

- Connect classroom work to professional practice

\subsection{General approach}

PBL was employed in two of the three blocks in the subject: the Electrical Installations block and the Lighting Installations block (see Table 1). It was used in two of the five general groups, groups D and E. Table 3 shows the working groups that were set up in each practical sub-group in each general group.

\begin{tabular}{|l|c|c|}
\cline { 2 - 3 } \multicolumn{1}{c|}{} & Group D & Group E \\
\hline Sub-group 1 & 13 & 8 \\
\hline Sub-group 2 & 11 & 9 \\
\hline Sub-group 3 & 10 & 11 \\
\hline
\end{tabular}

Table 3. "Working groups in each practical sub-group set up in general groups D and E". Source: authors

Below is an account of how the basic aspects of PBL and cooperative learning were addressed when designing the activity.

\section{$\underline{\text { Significant projects connected to professional practice }}$}

To achieve a strong connection between classroom work and professional practice, it was decided to run two significant projects featuring common issues in professional architectural activity. There would be one project for each of the two blocks.

- Block II. Electrical Installations: Electrical installation project for a block of flats. Length: half semester 
- Block III. Lighting Installations: Lighting project for business premises. Length: half semester

\section{Integration of various courses and subjects}

In order to establish links with other subjects such as Building Projects, Structures, Construction, and Installations 1 , the groups were encouraged to work either on their own building projects undertaken in the same year or in previous years, or on the building for which they were designing other installations that they had studied in another subject. The idea was for them to design the electrical and lighting installations of buildings they had planned architecturally in other subjects (Building Projects), while also taking into account structural design (Structures), building development (Construction) and the layout of the other installations to complete the overall building project.

\section{Guide of the project}

The students were given a comprehensive guide featuring the organization of work for each project to enable them to divide up the tasks to be performed based upon time. Appendix 1 contains extracts from the guidelines developed for carrying out the two projects.

\section{Cooperative work}

The projects were to be done in groups with a minimum of 3 students and a maximum of 5 . The final number was decided by each lecturer based on the total number of students he or she was teaching.

The workload of a $4^{\text {th }}$ year Architecture student was also taken into consideration. For this reason a system was used that allowed students to make the most of the 2,5 hours per week in their practical class so that they could keep their work up-todate. Each project was to be done over 6 sessions (one per week) and compulsory minimum attendance at 4 out of 6 sessions per block was established.

The goals for each session could be sent to the lecturer via the PoliformaT (Open Source Sakai Project) online platform that is available for each subject at the UPV. A deadline of 12 hours from the start of each session was set to hand in its goals. This deadline was designed to ensure that those groups that did not have enough 
time to finish in the 2,5 hour session could continue working collectively, taking advantage of the fact that they were already together. This approach to classroom work facilitated face-to-face interaction between the students.

The significance of each project and the amount of work to be done to deadlines ensured the positive interdependence of the members of each team.

Because some of the group work was done in the classroom in the presence of the lecturer, he or she was able to monitor the development of the students' cooperative skills through observation and in some cases resolve internal conflicts in the groups.

A "group form" was used to monitor the project and the overall functioning of cooperative work. The lecturer used it to keep the attendance register, make notes about the work submitted in each session and, where necessary, assess the functioning of the groups.

\section{Project assessment: public display of projects and importance in final mark}

There has been formative assessment of the projects.

The handing in of work done during the session was voluntary, but any group doing so was guaranteed weekly feedback on the progress of their project. In turn, those groups which corrected and improved their project were aware that they were guaranteed a pass mark for their project.

In the last session, the students had to present their projects in each block to the rest of the class together with a report. During the presentation any group member could be selected by the lecturer to explain any part of the installation. This established the individual accountability of each student in their group and vis-à-vis the lecturer.

At the end of the presentation the group was asked to mention any unresolved issues and to explain where they had had most difficulty. They were thus invited to think about the project and the work they had done one more time (group processing).

Successful completion of the project meant that students did not have to do the final practical exam, that is to say they had been continually assessed for the 
practical part of the subject by means of the two projects done, and those passing the projects only did the final theory exam.

Both projects accounted for $30 \%$ of the mark for the subject, with the remaining $70 \%$ coming from the final theory exam.

\section{Results}

\subsection{Assessment system}

To assess achievement of the goals (see Section 5.1) sought with the use of the method, the following assessment systems were used:

- System 1: Weekly monitoring of project development by observation

- System 2: Project marks

- System 3: Marks in the final theory exam

- System 4: Official UPV surveys and short surveys designed by the teachers of the subject with a space for making comments and suggestions.

Table 4 shows the assessment system used to evaluate each of the goals.

\begin{tabular}{|l|c|}
\hline \multicolumn{1}{|c|}{ Goal } & System \\
\hline $\begin{array}{l}\text { Improve learning } \\
\text { outcomes }\end{array}$ & $1,2,3$ \\
\hline $\begin{array}{l}\text { Promote independent } \\
\text { learning }\end{array}$ & $1,2,3$ \\
\hline Enhance motivation & 4 \\
\hline $\begin{array}{l}\text { Connect classroom work } \\
\text { with professional practice }\end{array}$ & 4 \\
\hline
\end{tabular}

Table 4. "Assessment system used to evaluate each of the goals". Source: authors

\subsection{Evaluation of goals: Improve learning outcomes and promote independent learning}

Achievement of the goals of improving learning outcomes and promoting independent learning was assessed using the systems 1,2 and 3 described in previous section (see Table 4). 
The results obtained with the system 1 have been collected in the notes that the teachers wrote in each group form during the sessions. The weekly monitoring of project development has assured the assimilation of the fundamental concepts and allowed the resolution of doubts. In addition, the use of this system has also prevented students from copying projects submitted in previous years. In terms of assessment, monitoring during each session and the review of work handed in during the semester meant that some groups which had submitted work that was worse than expected (defects in graphics, errors in transcribing results, small mistakes, etc.) were able get a better mark than they would have got if only the final result of the project had been assessed. Analysis of the information gathered by lecturers in the group forms shows that the final mark for the project was higher in the groups that persevered most.

Project marks and the results of the final theory exam are summarized in Table 5 and Figures 1 to 4 , respectively.

\begin{tabular}{|l|c|c|}
\hline \multicolumn{1}{|c|}{ Mark } & Electrical I. Project & Lighting I. Project \\
\hline Fail & $9.7 \%$ & $8.5 \%$ \\
\hline Pass & $35.5 \%$ & $28.8 \%$ \\
\hline Very good & $33.9 \%$ & $52.5 \%$ \\
\hline Excellent & $20.9 \%$ & $10.2 \%$ \\
\hline
\end{tabular}

Table 5. "Project marks in percentage". Source: authors

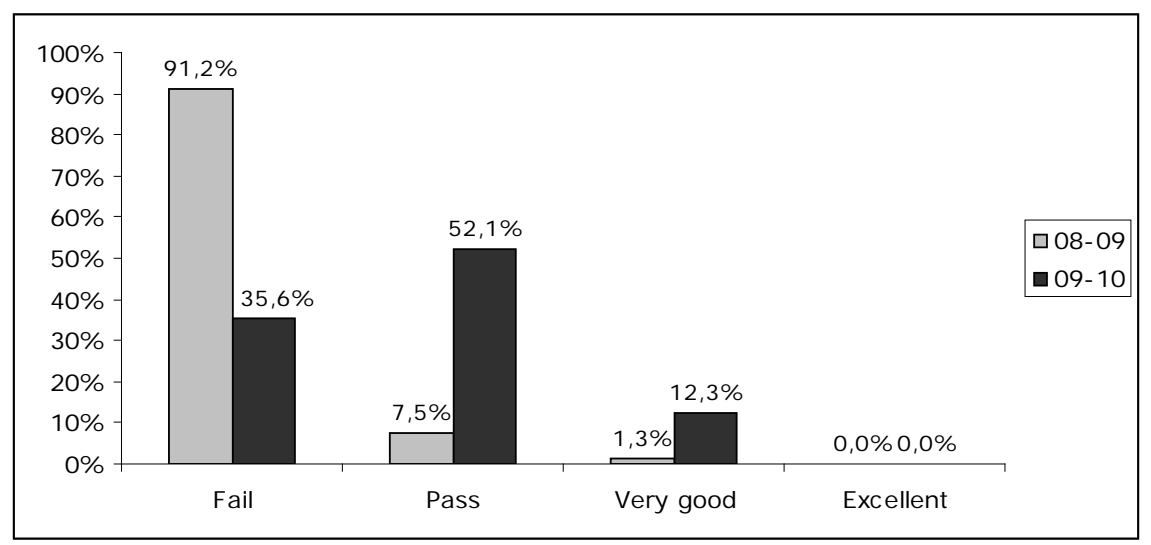

Figure 1. "Comparison of the GLOBAL results of the final theory exam of BLOCK II for academic years 08-09 and 09-10". Source: authors. 


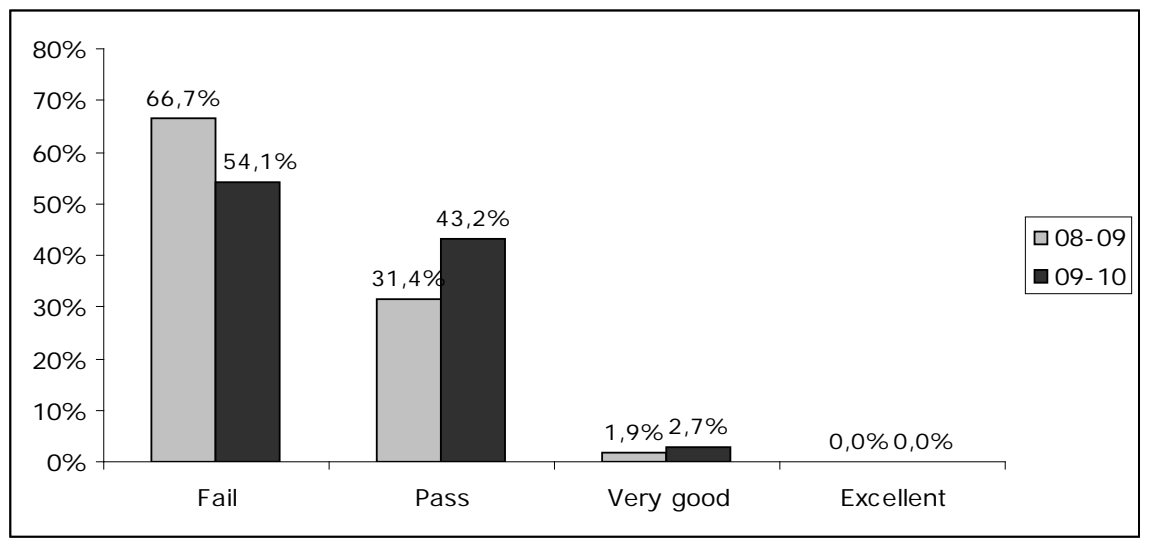

Figure 2. "Comparison of the GLOBAL results of the final theory exam of BLOCK III for academic years 08-09 and 09-10". Source: authors

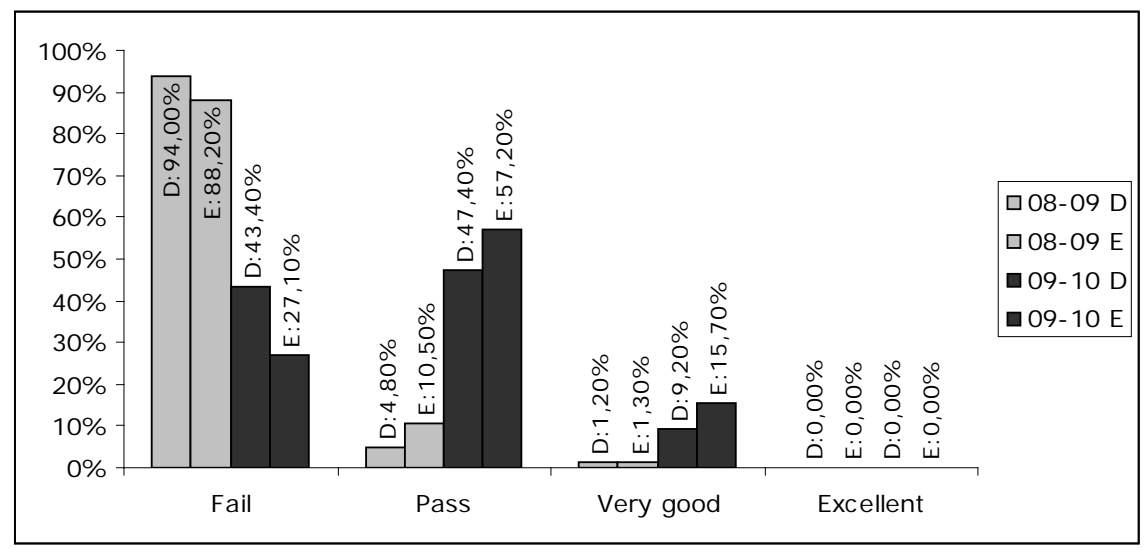

Figure 3. "Comparison of the results of the final theory exam of BLOCK II (groups D and E) for academic years 08-09 and 09-10". Source: authors

The results shown in Table 5 cannot be compared with results from previous years because, as was noted in Section 4, coursework was not assessed prior to the introduction of this method.

Figures 1 to 4 show a comparison between the June exam marks for the academic years 2008-09 and 2009-10. Note that in the academic year 08-09 this methodology was not applied. The exam had the same format and level of difficulty in both years.

As can be seen in Figures 1 to 4, there is a significant overall improvement in the results in the academic year 2009-10 with respect to the previous year. A more relevant improvement is achieved for Block II than for Block III. A possible 
explanation of this fact can be found by analyzing the contents of both blocks. Comparatively, the work in Block II is mechanical in front of the more creative work developed in Block III. This difference produces that the contents of Block II, being easier, in practice, they are less attractive for the students. In fact, the initial situation for Block II was worse than for Block III based on the final results (see Figures 1,2 ). As a result of the application of the methodology described, Block II has been presented more attractive and useful for professional practice than in past years. Therefore, since the contents of Block II are easier, the results of the final exam of this Block are better than the results of Block III which contents are really more difficult.

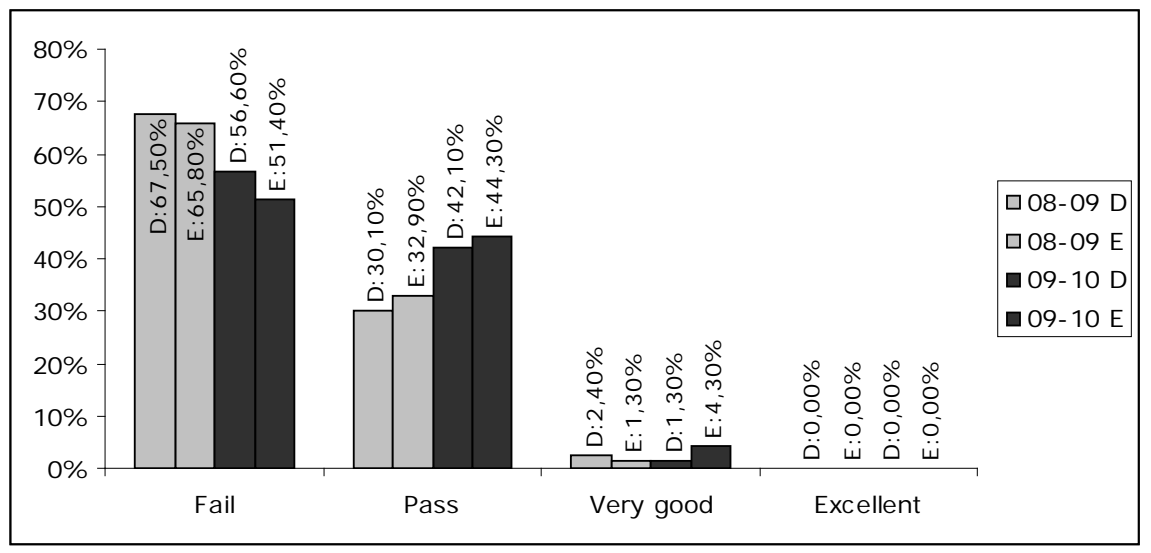

Figure 4. "Comparison of the results of the final theory exam of BLOCK III (groups D and E) for academic years 08-09 and 09-10". Source: authors

\subsection{Evaluation of goals: Enhance motivation and connect classroom work with professional practice}

The results of the surveys designed by the teachers of the subject and official UPV surveys were analyzed to see whether the goals of motivating and connecting the subject with professional practice had been achieved (system 4, see Table 4).

The surveys designed by the teachers for the academic year 2009-10 contained 12 questions to assess various aspects of the course in general. Two of the questions, questions 3 and 4, were designed to gather student ratings of motivation and connection with professional practice.

This survey was conducted in the 2 groups in which the method was used. It was taken by 46 and 25 students in Groups D and E respectively. The surveys were 
handed out in the last few days of class in both cases. Table 6 shows the results for the two questions in the survey directly related to motivation and professional practice.

The official UPV surveys of the academic year 2008-09 were answered by 32 students in Group D and 42 in Group E. The official UPV surveys of the academic year 2009-10 were answered by 22 students in Group D and 29 students in Group E.

\begin{tabular}{|c|c|c|c|c|}
\cline { 2 - 4 } \multicolumn{1}{c|}{} & \multicolumn{2}{c|}{ GROUP D } & \multicolumn{2}{c|}{ GROUP E } \\
\cline { 2 - 5 } & $\begin{array}{c}\text { Average } \\
\text { out of } 10\end{array}$ & $\begin{array}{c}\text { Standard } \\
\text { deviation }\end{array}$ & $\begin{array}{c}\text { Average } \\
\text { out of } 10\end{array}$ & $\begin{array}{c}\text { Standard } \\
\text { deviation }\end{array}$ \\
\hline $\begin{array}{c}\text { 3. The approach taken to the subject is useful for } \\
\text { professional practice. }\end{array}$ & 8.13 & 2.00 & 9.17 & 1.38 \\
\hline $\begin{array}{c}\text { 4. My interest in the subject has increased as a } \\
\text { result of this course. }\end{array}$ & 7.12 & 2.02 & 7.30 & 1.99 \\
\hline
\end{tabular}

Table 6. "Results of questions 3 and 4 in the survey given to students." Source: authors

The result of question 3 (see Table 6) shows that students consider that classroom work is connected to professional practice.

Students' increased motivation for the subject has been assessed by considering the results from the survey designed by the teachers (see Table 6, question 4) and results from the official UPV surveys. The comparative results between academic years 08-09 and 09-10 are as follows:

\begin{tabular}{|c|c|c|c|c|}
\hline \multirow{2}{*}{ Academic year } & \multicolumn{2}{|c|}{ UPV surveys } & \multicolumn{2}{c|}{ Teachers' survey } \\
\cline { 2 - 5 } & $\begin{array}{c}\text { Average (out } \\
\text { of 10) }\end{array}$ & $\begin{array}{c}\text { Standard } \\
\text { deviation }\end{array}$ & $\begin{array}{c}\text { Average (out } \\
\text { of 10) }\end{array}$ & $\begin{array}{c}\text { Standard } \\
\text { deviation }\end{array}$ \\
\hline $2008-09$ & Group D: 5.73 & 3.37 & - & - \\
& Group E: 6.22 & 2.48 & - & 2,02 \\
\hline $2009-10$ & Group D: 7.73 & 2.91 & Group D: 7.12 & 1.99 \\
\hline
\end{tabular}

Table 7. "Assessment of motivation". Source: authors

The first row of Table 7 shows the score in the motivation section of the official UPV surveys in 2008-09. The second row indicates the score in the motivation section of the official UPV surveys and the score for question 4 in the survey given to students, both in 2009-10. 
The results shown in Table 7 indicate that the methodology employed has promoted a major motivation of the students for the subject in comparison with the previous year.

\subsection{Overall assessment of the methodology}

The overall assessment of the methodology by the students has been analyzed using the results of the official UPV surveys of the academic year 2008-09 and 2009-10. It has been analyzed the question: "The methodology and the activities realized in the subject help to learn". The results are shown in Table 8.

\begin{tabular}{|c|c|c|}
\hline Academic year & Average (out of 10) & Standard deviation \\
\hline $2008-09$ & Group D: 6.05 & 2.75 \\
& Group E: 6.65 & 2.68 \\
\hline $2009-10$ & Group D: 8.52 & 1.95 \\
& Group E: 8.04 & 2.04 \\
\hline
\end{tabular}

Table 8. "Overall assessment of the methodology by the students". Source: authors

In Table 8 is observed that the students have assessed very positively the methodology in comparison with the previous course, where PBL was not applied.

\section{Conclusions}

This paper has presented the use of Project-Based Learning in the subject "Acondicionamiento y servicios 2" at the Escuela de Arquitectura at the Universitat Politècnica de València.

The results show that the goals (motivation, improved learning outcomes, independent learning and connection with professional practice) which led to the introduction of this kind of learning have been achieved. In their written comments in the surveys the students gave a positive rating to the method used for their course projects, with particular emphasis on the feedback received.

The main factors that helped with using the new method were the length of each practical class $(2,5$ hours) and the practical nature of the subject matter. Also, group work and project development were significantly assisted by the experience and knowledge already acquired by $4^{\text {th }}$ year Architecture students. On the other 
hand, the main variable that hindered the use of the method was the large number of students per practical sub-group, i.e. 40 .

Cooperative work applied in the presented methodology could present some drawbacks such as shirking. To prevent this disadvantage, the students had to present their projects to the rest of the class. During the presentation any group member could be selected by the lecturer to explain any part of the project and to answer any question. All the members of each group obtained the same mark, except in the case of three students who obtained lower mark because they were selected to present the project and were not able to explain it.

Based on this satisfactory experience, PBL can be specially useful to practical subjects of Architecture degree such as: Installations 1 (installations of water, gas and air conditioning), Structures and Construction.

As future work and considering that the subject has to be adapted to the European Space for Higher Education, the plan is to increase the percentage of the project mark up to 40-50\% of the final subject mark. In addition, there are being introducing new methodologies in theory classes (i.e. active learning, informal cooperative work,...) in order to improve learning outcomes. All these changes will be implanted shortly in all the groups, included those where the number of students is about 100 . 


\section{Appendix 1. Extracts from the guidelines developed for carrying out the projects}

\section{ORGANI ZATI ON OF THE LI GHTI NG PROJ ECT}

\section{SUBJ ECT: LIGHTING PROJ ECT FOR PUBLIC USE PREMISES}

GOALS: At the end of the project, students will be able to develop a lighting project for a given facility. They will learn to choose and differentiate the type of lighting best suited to each use and function, as well as the lamps and luminaires to achieve it.

METHOD: Cooperative learning over the course of 6 sessions in practical classes.

GROUP SIZE: 3, 4 or 5 people. (The lecturer specifies the number of members.)

\section{MATERI ALS:}

Basic: teaching material (PoliformaT)

Specific: indicated in each session

TASKS: Before the start of the first session students will:

1. Form working groups and fill in the group form (PoliformaT). They will also choose the group's spokesperson.

2. Find a block of flats (the same one for both the electrical installation and lighting project). The lighting project will be developed for the building's business premises. The business activity of these premises will be decided by the lecturer. It is recommended to choose a building designed by the student in the subject "Building Projects" or use the same building used for practical work in the subject “Installations 1 '.

The building will have at least the following features and services:

- Upper floor flats

- Business premises on the ground floor or mezzanine

- Garage with or without storage rooms 
- Lift(s) and water booster pump(s)

To make it easier to carry out the project, it is a good idea to have the building plans (floor plans, elevations and sections) in *.dwg or another format.

3. Read the description of the sessions given below in this document.

SUCCESS CRITERIA: At the end of each session each team will hand in the part of the installation indicated.

During the last session, the project will be presented to the rest of the class and all team members should be able to explain and defend any part of it.

The mark for this lighting project is $15 \%$ of the final mark for the course.

Assessment will be individual and will be done using information about each student based on the lecturer's opinion of their academic performance.

Students must attend at least $2 / 3$ of the sessions if they want to pass the practical part of the subject.

\section{RECOMMENDATI ONS:}

- Bring a laptop to the sessions

- Bring notes and material from theory classes

- Read the programme for each session sufficiently far in advance 


\section{SESSION 2 I N THE ELECTRI CAL I NSTALLATI ON PROJ ECT}

Topic: GENERAL ELECTRICAL ORGANIZATION IN THE BUILDING AND PROJECT IMPLEMENTATION: INSTALLATION OF POWER DISTRIBUTION FACILITY 1

\section{Session goals:}

1. Establish the power supply to the building based on the loads obtained in Session 1. Decide about the transformer substation.

2. Power distribution facility design: draw all power distribution facility fixtures in the building in their location. Draw the route of the lines. Rearrange and resize, if necessary, common elements and areas set aside for the installations.

3. Set out the general layout of the building's electrical installation in a single-line diagram, following the explanations given in theoretical classes.

4. Calculation of the power distribution facility: diagram of the consumer unit and sizing of the general power line.

\section{Materials:}

- Building plans on a computer or printed

- Low-voltage electrical regulations

- Subject materials in PoliformaT

- Printed: EE-6 Instalaciones eléctricas de baja tensión de un edificio destinado a viviendas de la Consellería de Industria, Comercio e Innovación

- Summary of Common Telecommunications Infrastructure

- Calculation tables (general power line table, UNE table, DI pipes table, protective conductor table)

\section{Planning:}

1 hour 15 min: goals 1 and 2

15 min: goal 3 
1 hour: goal 4

\section{Exercise to hand in:}

At the end of the session the following will be handed in using the PoliformaT "TASKS" tool:

- Floor plans and sections with the power distribution facility drawn

- Single-line diagram of the power distribution facility

- Grounds for the calculation of the general power line and consumer unit

- EE- 6 form with the appropriate sections filled in 


\section{SESSION 6 IN THE ELECTRI CAL I NSTALLATI ON PROJ ECT \\ PUBLIC PRESENTATION OF PROJECTS}

\section{Panels}

$4 \mathrm{~A} 2$ bearing the following information:

- Floor plans and section with the power distribution facility. E 1/100

- Panel plan and meter enclosure

- Electro-functional plans for the housing units, common areas and garage. E $1 / 50$

- Housing unit circuit structural diagram. E 1/50

- Complete diagram with sizing

\section{Review summary}

- Load calculation summary

- Printed: EE-6 Instalaciones eléctricas de baja tensión de un edificio destinado a viviendas de la Consellería de Industria, Comercio e Innovación

- Summary of the installation inside the housing unit, common areas and garage

- Summary of the reasoning for all calculations performed with the specifications of the lines

\section{Presentation of projects}

All team members must be able to defend the design of the installation and the calculations made, since a group member chosen at random by the lecturer will be asked to explain the project. 


\section{Acknowledgments}

The work presented in this paper has been developed within the research group Equipo de Innovación y Calidad Educativa (EICE) Pro-Inmedo (Proyectos de Innovación y Mejora Docente Interdisciplinar) of the Universitat Politècnica de València.

The translation of this paper was funded by the Universitat Politècnica de València, Spain.

\section{References}

Alcocer, J., Ruíz, S., \& Valero-García, M. (2003). Evaluación de la implantación de aprendizaje basado en proyectos en la EPSC. Paper presented at XI Congreso Universitario de Innovación Educativa en Enseñanzas Técnicas.

Blank, W. (1997). Authentic instruction. In W.E. Blank \& S. Harwell (Eds.), Promising practices for connecting high school to the real world. Tampa, FL: University of South Florida. (ERIC Document Reproduction Service No. ED407586).

Fernández, A. (2003). Formación pedagógica y desarrollo profesional de los profesores de universidad: análisis de las diferentes estrategias. Revista de Educación, 331, 171-199.

Harwell, S. (1997). Project-based learning. In W.E. Blank \& S. Harwell (Eds.), Promising practices for connecting high school to the real world. Tampa, FL: University of South Florida. (ERIC Document Reproduction Service No. ED407586).

Johnson, D. W., Johnson, R. T., \& Smith, K.A. (1991). Active Learning: Cooperation in the College Classroom. Edina, Minnesota: Interaction Book Company.

Kjersdam, F., \& Enemark, S. (1994). The Aalborg Experiment. Aalborg University Press.

Martí, E., Gil, D., Vivet, M., \& Julià, C. (2009). Aprendizaje Basado en Proyectos en la asignatura de Gráficos por Computador en Ingeniería Informática. Balance de 
cuatro años de experiencia. Paper presented at XV Jornadas de Enseñanza Universitaria de la Informática. Barcelona.

Reverte Bernabeu, J.R., Gallego Sánchez, A.J., Molina Carmona, R., Satorre Cuerda, R. (2007). El Aprendizaje Basado en Proyectos como modelo docente. Experiencia interdisciplinar y herramientas Groupware. Paper presented at XIII Jornadas de Enseñanza Universitaria de la Informática. Teruel.

Valero-García, M. (2010). El aprendizaje basado en proyectos, en los estudios de Ingeniería. Cuadernos de pedagogía, 403, 1-.

Woods, D.R., et al. (2000). The future of engineering education. Developing critical skills. Chemical Engineering Education, 34(2), 108-117.

Woods, D.R. (1994). Problem-based learning: How to gain the most from PB. MC Master University.

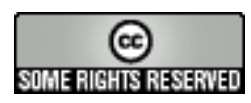

Article's contents are provided on a Attribution-Non Commercial 3.0 Creative commons license. Readers are allowed to copy, distribute and communicate article's contents, provided the author's and Journal of Industrial Engineering and Management's names are included. It must not be used for commercial purposes. To see the complete license contents, please visit http://creativecommons.org/licenses/by-nc/3.0/. 